\title{
PREVALENCE OF TOXOPLASMOSIS IN RABBITS IN SOUTH BOHEMIA
}

\author{
K. HEJLIČEK ${ }^{1}$ and I. LITERÁ ${ }^{2}$ \\ „„VEDIA”, Private veterinary laboratory, 38601 Strakonice \\ ${ }^{2}$ Department of Infectious Diseases and Epizootiology, University of Veterinary and Pharmaceutical \\ Sciences, 61242 Brno
}

Received March 24, 1994

\begin{abstract}
Hejlícek K., I. Literák: Prevalence of Toxoplasmosis in Rabbits in South Bohemia. Acta vet. Brno, 63, 1994: 145-150.

The incidence and prevalence of toxoplasmosis in rabbits in small flocks in the district of Strakonice was investigated from 1981 to 1986.

A total of 366 slaughter rabbits from 48 small flocks were examined using Sabin-Feldman dye test (DT) and isolation attempts. Toxoplasma gondii antibodies were detected in 194 (53.0\%) rabbits and the causative agent was demonstrated in the tissues of $54(17.8 \%)$ out of 304 rabbits in which bio-assay was concluded. Of the 54 slaughter rabbits having $T$. gondii in the tissues $18(33.3 \%)$ were devoid of antibodies when examined with DT at slaughter. Of the 48 husbandmen 36 supplied 5 or more rabbits. In all these 36 small flocks rabbits with T. gondii antibodies were found and in $23(63.9 \%)$ of them the causative agent was demonstrated.

In 4 other small flocks 86 blood serum samples were examined with DT upon repeated blood collections; $62(72.1 \%)$ of them showed $T$. gondii antibodies. The incidence of antibodies varied from flock to flock, ranging between $44 \%$ and $84 \%$, and the highest titre was 16384 . At blood collections repeated several times during one year some rabbits showed marked seroconversion and retained high antibody titres. One rabbit, however, in the same flock had no antibodies or showed them at the titre of 4 at the highest.

Toxoplasmosis continues to be a problem in small flocks of rabbits, posing serious hygienic and epidemiological hazards. Slaughter rabbits from small flock are the most $T$. gondii - affected of all common slaughter animal species. Considering the increasing production of rabbit meat due attention to toxoplasmosis in rabbits is required.
\end{abstract}

Rabbit, Toxoplasma gondii, antibody, isolation, small flocks.

Toxoplasmosis in rabbits has received less attention in the world literature than toxoplasmosis in other farm animal species. Some relevant data are to be found in the monograph by Dubey and B e at tie (1988).

In our country $H a v l i k$ and $H u ̈ b n e r$ drew attention to the incidence of toxoplasmosis in rabbits in 1960. Having examined blood sera of 110 rabbits from 10 flocks with Sabin-Feldman dye test (DT) they detected Toxoplasma gondii antibodies in $94.5 \%$ of the sera in titres of 4 to 1048576 . In their isolation attempts they demonstrated the presence of $T$. gondii in 2 out of 8 rabbits included in the experiment. The prevalence of $T$. gondii antibody in the sera of rabbits from all 10 flocks was approximately the same. Similar results were later reported by Zástěr ra et al. (1966) who using DT found $T$. gondii antibodies in $91.3 \%$ of the sera and drew attention to possible connexion between toxoplasmosis in rabbits and $T$. gondii infection in man. Hubner and Uhlíková (1970) using microprecipitation in agar gel detected $T$. gondii antibodies in the sera of $23.2 \%$ of rabbits, Si i ma and R a šin (1973) examining a large sample of slaughter rabbits with the complement-fixation test (CFT) found T. gondii antibodies in 54.9\% of the animals and L u kešová et al. (1984) using DT detected T. gondii antibodies in 86.4\% of the rabbits examined. According to the Surveillance of Anthropozoonoses in the Czech Republic in 1980 to 1988 the proportion of rabbits serologically positive for toxoplasmosis by DT was $42.8 \%$ and isolation attempts yielded $T$. gondii in $11.3 \%$ of the rabbits examined.

Infection of rabbits with $T$. gondii is generally not manifested by clinical signs of disease. In some cases, however, clinical manifestations of the disease were described including injury to the CNS, paralysis of hind limbs, abortion, congenital hydrocephalus, together with more general symptoms such as inappetence, emaciation, rhinitis and enteritis (Peeters and Halen 1978, Manfredini 1978, Zardi et al. 1979, Bergmann et al. 1980). The infection is caused by ingestion of feed contaminated with $T$. gondii oocysts (Peeters and Halen 1978, Jan it schke 1979, Malukie ne 1989a). Nevertheless, toxoplasmosis in rabbits may apparently be also due to congenital transmission (Uhlík ová and Hübner 1973, Werner et al. 1977).

Rabbits are highly susceptible to $T$. gondii infection. Differences, however, exist in the degree of infection, depending on husbandry conditions ( $\mathbf{S}$ i m a and Rasín 1973, Peeters et al. 1979) as well as on individual susceptibility (Malukiene 1989b).

The present report was designed as part of our comprehensive study on epizootiology of toxoplasmosis in the district of Strakonice in the 1980's (Hejlíce k and Li terák 1992, 1993 a, b, Literák et al. 1992, Literák and Hejlíce k 1993) with the objective to assess the incidence of $T$. gondii antibodies and of the causative agent in 
rabbits kept in small flocks under traditional husbandry and feeding practices, compare these results with the incidence of toxoplasmosis in other animal species and evaluate the development in the incidence of toxoplasmosis in rabbit flocks in the area under study from the 1960's to the present time.

\section{Materials and Methods}

A total of 366 slaughter rabbits coming from 48 small flocks in the distict of Strakonice in the Czech Republic were examined for toxoplasmosis in September to November 1984. Blood samples and liver, diaphragm and brain specimens were collected at slaughter. The blood sera were examined with Sabin-Feldman dye test (DT) according to the standard method of the Central State Veterinary Institute, Prague, only in the dilution of 1:4. From the liver, diaphragm and brain specimens of each rabbit a pooled suspension was prepared in buffered saline with antibiotics (600 000 IU penicillin $\mathrm{G}$ and $1 \mathrm{~g}$ streptomycin in $1000 \mathrm{ml}$ saline) and injected intraperitoneally into two toxoplasma-negative mice. Unless the mice died earlier, they were killed and exsanguinated after 5 weeks. Their sera were examined with DT. From their brains compressive preparations were prepared for demonstration of $T$. gondii cysts. The result of bioassay on mice was regarded as positive if specific antibodies were detected in their blood sera with DT at the titre of 4.

In other 4 small randomly chosen flocks in the same district rabbits were repeatedly subjected to serological examination with DT and to examination with microprecipitation in agar gel (MPA) from 1981 to 1986. MPA was carried out using kits and according to the method of the Institute of Sera and Vaccines, Prague. The examinations were made regularly at 3-months intervals. In DT the final titre level was assessed whenever a sufficient serum volume was available. The initial dilution was 1:4. In MPA the presence of precipitating antibodies was evaluated only qualitatively.

\section{Results}

A total of 366 slaughter rabbits were examined. Of these 194 (53.0\%) exhibited $T$. gondii antibodies upon examination with DT. Of 304 rabbits in which bio-assay on mice was concluded $54(17.8 \%)$ were found to have $T$. gondii in the tissue specimens examined.

Of the 54 rabbits in whose tissues the presence of $T$. gondii was demonstrated by bio-assay $36(66.6 \%)$ had $T$. gondii antibodies in their sera when examined with DT; the remaining 18 $(33.3 \%)$ rabbits were without antibodies.

In 36 flocks the examination covered 5 or more rabbits. In all these flocks rabbits with $T$. gondii antibodies were found and in 23 (63.9\%) of these flocks $T$. gondii were demonstrated by bio-assay.

Table 1

Incidence of $T$. gondii antibodies in rabbits from small flocks in the distict of Strakonice examined for a considerable length of time using Sabin-Feldman dye test

\begin{tabular}{|c|c|c|c|c|c|c|c|c|c|c|c|c|c|c|c|}
\hline $\begin{array}{c}\text { Flock } \\
\text { No. }\end{array}$ & $\begin{array}{c}\text { No. } \\
\text { rabbits } \\
\text { examined }\end{array}$ & $\begin{array}{l}\text { No. } \\
\text { rabbits } \\
\text { positive }\end{array}$ & 4 & 8 & 16 & 32 & 64 & 128 & 256 & 512 & 1024 & 2048 & 8192 & 16384 & ${ }^{x} g$ \\
\hline $\begin{array}{l}\text { I } \\
\text { II } \\
\text { III } \\
\text { IV }\end{array}$ & $\begin{array}{c}43 \\
15 \\
9 \\
19\end{array}$ & $\begin{array}{c}34(79 \%) \\
8(53 \%) \\
4(44 \%) \\
16(84 \%)\end{array}$ & $\begin{array}{l}4 \\
5 \\
2 \\
7\end{array}$ & $\begin{array}{l}\overline{2} \\
1 \\
3\end{array}$ & $\begin{array}{l}3 \\
1 \\
1 \\
3\end{array}$ & $\begin{array}{l}1 \\
- \\
-\end{array}$ & $\begin{array}{l}3 \\
\overline{1} \\
\overline{1}\end{array}$ & $\begin{array}{l}5 \\
- \\
-\end{array}$ & $\begin{array}{l}2 \\
- \\
-\end{array}$ & $\begin{array}{l}1 \\
\overline{1}\end{array}$ & $\begin{array}{l}11 \\
- \\
- \\
-\end{array}$ & $\begin{array}{l}1 \\
- \\
-\end{array}$ & $\begin{array}{l}1 \\
- \\
-\end{array}$ & $\begin{array}{l}2 \\
- \\
- \\
-\end{array}$ & $\begin{array}{r}222 \\
6 \\
7 \\
12\end{array}$ \\
\hline Total & 86 & $62(72,1 \%)$ & 18 & 6 & 8 & 1 & 4 & 6 & 2 & 2 & 11 & 1 & 1 & 2 & 52 \\
\hline
\end{tabular}

${ }^{\mathrm{x}} \mathrm{g}=$ mean geometric titre

In 4 other small flocks (Nos. I to IV) where rabbits were blood-sampled repeatedly (Table 1) a total of 86 blood serum samples were examined with DT. Of these serum samples 62 (72.1\%) showed T. gondii antibodies in the mean geometric $\left(\overline{\mathrm{x}}_{\mathrm{g}}\right)$ titre of 52. The antibodies were found in rabbits of all 4 flocks, even though at varying frequency ( $44 \%$ to $84 \%$ ) and $\bar{x}_{\text {}}$ level (6 to 222). Very high titres were found in flock I and low titres, in flocks II and III. Of 66 blood serum samples examined with MPA 27 (40,9\%) exhibited precipitating antibodies. The difference in the incidence of antibodies detected with DT and MPA was highly significant $\left(\chi^{2}=16.3 \mathrm{df}=1 \mathrm{P}<0.001\right)$. 
Table 2

Dynamics of the incidence of $T$. gondii antibodies in the sera of rabbits from small flocks examined with Sabin-Feldman dye test ( $\mathrm{n}=$ not examined, $+=$ seroconversion)

\begin{tabular}{|c|c|c|c|c|c|c|c|c|c|c|c|c|}
\hline $\begin{array}{l}\text { Rabbit } \\
\text { No. }\end{array}$ & 4 & & (8) & 10 & Mon & 4 & 7 & 10 & 1 & 4 & $\begin{array}{c}\text { Year of the 1st } \\
\text { blood } \\
\text { collection }\end{array}$ & $\begin{array}{c}\text { Flock } \\
\text { No. }\end{array}$ \\
\hline $\begin{array}{l}1 \\
2 \\
3 \\
4 \\
5 \\
6 \\
7\end{array}$ & $\begin{array}{l}0 \\
0\end{array}$ & $\begin{array}{c}256 \\
128 \\
n \\
128 \\
4\end{array}$ & $\begin{array}{c}+(1024) \\
(\mathrm{n}) \\
(8192) \\
(\mathrm{n}) \\
2+1024 \\
(0)\end{array}$ & $\begin{array}{c}1024 \\
+1024 \\
21024 \\
2+1024 \\
\geq 64 \\
n \\
4\end{array}$ & $\begin{array}{c}512 \\
128 \\
1024 \\
1024 \\
2048 \\
4 \\
4\end{array}$ & $\begin{array}{c}1024 \\
32 \\
+16384 \\
21024 \\
0 \\
n\end{array}$ & $\begin{array}{c}128 \\
1024\end{array}$ & 0 & 4 & 0 & $\begin{array}{l}1983 \\
1983 \\
1983 \\
1983 \\
1983 \\
1983 \\
1981\end{array}$ & $\begin{array}{l}\text { I } \\
\text { I } \\
\text { I } \\
\text { I } \\
\text { I } \\
\text { I } \\
\text { II }\end{array}$ \\
\hline
\end{tabular}

In some rabbits of flocks I and II blood serum examination was carried out 3 to 7 times during a period of at least 9 months (Table 2). Rabbits Nos. 1 to 5 of flock I retained high antibody titres upon repeated examination and all animals of this flock showed marked seroconversion. In the same flock, however, rabbit No. 6 examined during the same period showed either the antibody titre of 4 at the highest or no antibodies at all. Similarly, in rabbit No. 7 of flock II the result of SFT alternated between positive and negative during a period of more than 18 months, the titre of 4 being the highest.

\section{Discussion}

Since the spread of toxoplasmosis in rabbit flocks in this country was first reported in the 60 's and its epidemiological impact was suggested, a number of observations on the epizootiology of toxoplasmosis in domestic and free-living animals have been made. In the past 30 years a decrease in the prevalence of toxoplasmosis in slaughter cattle, pigs and domestic fowls was recorded in connexion with the increasing adoption of intensive husbandry practices (Hejlíček and Literák 1992, 1993a, Literák and Hejlíček 1993). In rabbits kept in small traditional flocks the situation, however, remains approximately the same as was described by Havlík and Hübner (1960), Zástěra et al. (1966) and Sím a and R ašin (1973). In agreement with Ha vlík and Hüb b e r (1960) we regard rabbits as highly susceptible to $T$. gondii as evidenced by the high frequency of the incidence of antibody and causative agent as well as by high antibody titres. A possible explanation can be seen in the fact that since the 60's the husbandry and feeding practices in rabbit flocks have remained unchanged, i. e. use is made mainly of green forage from areas surrounding the farm buildings to which domestic cats have free access and which apparently are heavily contaminated with $T$. gondii oocysts from feline faeces. The crucial role of green forage from oocyst-contaminated areas in the transmission of toxoplasmosis to rabbits was demonstrated experimentally by Malukiene (1989a). Added to this is possible congenital transmission (Uhlíková and Hübner 1973, Werner et al. 1977) or transmission through milk (Rommel and Breuning 1967) and not even transmission through saliva (Ter$\mathrm{rag} \mathrm{na}$ et al. 1984) or urine (W i ck h a m and Carne 1950) of infected rabbits can be excluded. The differences in the incidence of $T$. gondii antibodies between the small flocks are, in our view, due to different epizootiological situations and particularly to different degrees of environmental contamination with $T$. gondii oocysts.

A different epizootiological situation exists in large flocks. Šíma and Rašín (1973) using CFT found that the proportion of slaughter rabbits with $T$. gondii antibodies coming from a large flock was $38.4 \%$, with antibody titres over 160 being detected in $0.42 \%$ of the animals; in rabbits from small flocks, on the other hand, $T$. gondii antibodies were found by them in $57.9 \%$ of the rabbits, with titres over 160 being detected in $8.1 \%$ of the animals. 
Similarly, Pe e ters et al. (1979) reported that the proportion of serologically-positive rabbits was $22.8 \%$ in small traditional flocks of rabbits fed on green forage and only $0.97 \%$ in rabbits fed granulated feed under intensive husbandry conditions.

Of interest was the finding of rabbits without $T$. gondii antibodies or showing only occasional low antibody titres in flocks heavily contaminated with toxoplasmosis. Similar observations were made in rabbits experimentally infected with $T$. gondii oocysts by $\mathrm{Mal}$ u k i e $\mathrm{ne}(1989 \mathrm{~b})$. He explained this finding by differences in the susceptibility of individual animals, which becomes particularly apparent in infections with small numbers of oocysts.

As it is, rabbits kept in small flocks are still the most $T$. gondii-affected among all the other farm animals, similarly to the findings reported 30 years ago, as became apparent from our studies on toxoplasmosis in cattle, pigs, sheep and domestic fowls in the district of Strakonice (Hejlíček and Literák 1992, 1993ab, Literák and Hejlíček 1993).

A fact of major importance from the diagnostic point of view in our opinion is the finding that a third of slaughter rabbits in which $T$. gondii were demonstrated had no T. gondii antibodies detectable with DT at slaughter. These cases may have represented either recentlyinfected animals in which antibodies had not yet developed or subjects in which antibody response had waned although $T$. gondii cysts survived in the tissues.

The main hazard of $T$. gondii transmission from rabbits to man lies in consumption of insufficiently heat-treated tissues and in the handling of rabbits at slaughter if principles of personal hygiene are disregarded. Even $T$. gondii transmission to attendants cannot be excluded, particularly if the animals are in the acute stage of toxoplasmosis. These hazards should be kept in mind in view of an increasing number of private flocks of considerable size in our country.

Toxoplasmosis in rabbits deserves full epizootiological and hygienic attention. According to the Ministry of Agriculture of the Czech Republic the number of rabbits kept in our country is expected to rise from 13.1 million in 1993 to 14.5 million in 1994. It is estimated that in 1994 a total of 160000 to 180000 tons of rabbit meat will come to the market and that 25000 tons of rabbit meat will be consumed by the husbandmen themselves. Thus the consumption of rabbit meat per person in our country in 1994 is estimated to reach $2.5 \mathrm{~kg}$.

\section{Prevalence toxoplazmózy králíků v jižních Čechách}

V letech 1981-1986 byl sledován výskyt a rozšíření toxoplazmózy králíků v malých chovech na okrese Strakonice.

Bylo vyšetřeno Sabin-Feldmanovou reakcí (SFR) a izolačním pokusem 366 jatečných králíkủ pocházejících ze 48 malých chovů. Protilátky proti toxoplazmóze byly zjištěny u 194 $(53,0 \%)$ králíkủ, původce byl prokázán ve tkáních 54 (17,8 \%) králíkủ ze 304, u nichž byl dokončen biologický pokus. Z 54 jatečných králíkủ s nálezem $T$. gondii ve tkáních $18(33,3 \%)$ bylo při porážce bez SFR protilátek. Ze 48 chovatelủ dodalo 36 prí nákupu 5 a více králíků. Ve všech 36 malých chovech byli králíci se SFR protilátkami, ve 23 chovech $(63,9 \%)$ byla u králíkủ prokázána $T$. gondii.

Ve 4 jiných malých chovech bylo při opakovaných odběrech vyšetřeno SFR 86 vzorků krevního séra, $\mathrm{z}$ toho $62(72,1 \%)$ bylo s nálezem protilátek. Výskyt SFR protilátek v jednotlivých chovech se pohyboval od 44 do $84 \%$, maximální zjištěný titr byl 16384 . Př opakovaných odběrech $\mathrm{v}$ prủběhu roku byla u některých králíkủ prokázána výrazná sérokonverze a dlouhodobé přetrvávání vysokých titrů protilátek. $V$ témže chovu se však vyskytl jedinec bez SFR protilátek nebo s titrem maximálně 4 .

Toxoplazmóza zůstává $v$ malých chovech králíků trvale rozšírena a představuje významné hygienické a epidemiologické riziko. Jateční králíci z malochovủ jsou toxoplazmózou 
postihováni nejvíce ze všech běžných druhů jatečných zvírat. Vzhledem k narůstající produkci králič́ho masa vyžaduje toxoplazmóza králíkủ plnou pozornost.

\section{Прөобладание токсоплазмоза кроликов в южной Чөхии}

В 1981-1986 гг. исследовали наличие и распространение токсоплазмоза на небольших кролиководческих фермах района Страконице.

Исследовали реакцией Сабин-Фельдмана (SFR) и изоляционным экспериментом 366 кроликов, содержащихся на 48 небольших кролиководческих фермах. Антитела против токсоплазмоза были выявлены у 194 (53,0 \%) кроликов, возбудитель был установлен в тканях 54 $(17,8 \%)$ кроликов из 304, у которых завершили биологический эксперимент. Из 54 кроликов с результатом T. gondiï в тканях 18 (33,3\%) при умершвлении осталось без наличия SFR антител. Все 48 кролиководов поставили 36 при покупке 5 и больше кроликов. Из всех 36 кролиководческих хозяйств находились кролики с SFR антителами, у 23 кролиководческих ферм $(63,9 \%)$ у кроликов были выявлены T. gondii.

В других 4 небольших хозяйствах при повторном отборе исследовали SFR 86 образцов сыворотки крови, из этого 62 (72,1 \%) образцов содержали антитела. Наличие SFR антител в отдельных кролиководствах достигало 44-84 \%, предельный установленный титр - 16384 . При повторном отборе в течение года у некоторых кроликов были установлены сероконверсия и длительное наличие высоких титров антител. В том же кролиководстве имелись однако особи без SFR антител или с предельным титром 4.

Токсоплазмоз в небольших кролиководствах отличается постоянным распространением и представляет собою немаловажный гигиенический и эпидемиологический риск. Убойные кролики небольших кролиководческих хозяйств страдают токсоплазмозом больше других обычных видов убойных животных. Учитывая нарастающее количество кроличьего мяса, токсоплазмоз кроликов нуждается в пристальном внимании.

\section{References}

BERGMANN, V.-HEIDRICH, R.-KINPEL, H.: Akute Toxoplasmose - Ausbrüche in Kaninchenbeständen. Angew. Parasit., 21, 1980: 1-6

DUBEY, J. P.-BEATTIE, C. P.: Toxoplasmosis of Animals and Man. CRC Press, Inc. Boca Raton, Florida, 1988

HAVLfK, O.-HÜBNER, J.: Výskyt toxoplazmózy v chovech králíkủ v ČSR. Českoslov. Epidem. Mikrobiol. Imunol., 9, 1960: 16-22

HEJLIČEK, K.-LITERÁ, I.: Occurrence of toxoplasmosis and its prevalence in cattle in the South Bohemian region. Acta vet. Brno, 61, 1992: 195-206

HEJLICEEK, K.-LITERAK, I.: Prevalence of toxoplasmosis in pigs in the region of South Bohemia. Acta vet. Brno, 62, 1993: 159-166

HEJLIČEK, K.-LITERAK, I.: Toxoplazmóza jatečných ovcí. Veterinářství, 43, 1993: 414-417

HÜBNER, J.-UHLfKOVA, M.: Use of the microprecipitation method in agar gel (MPA) in the diagnostics of toxoplasmosis. II. Correlation of MPA and the SFT (Sabin-Feldman dye test) with results of Toxoplasma gondii isolation experiments. J. Hyg. Epidem. Praha, 14, 1970: 499-506

HUTCHISON, W. M.-DUNACHIE, J. F.-WORK, K.-SIIM, J. C.: The life cycle of the coccidian parasite Toxoplasma gondii in the domestic cat. Trans. roy. Soc. trop. Med. Hyg., 65, 1971, 380-399

JANITSCHKE, K.: Übertragung von Toxoplasma-Oozysten durch Hauskatzen auf Kaninchen. Zbl. Bakt. Hyg., I. Abt. Orig. A 245, 1979: 544-548

LITERAK, I.-HEJLIČEK, K.-NEZVAL, J.-FOLK, C.: Incidence of Toxoplasma gondii in populations of wild birds in the Czech Republic. Avian Pathology, 21, 1992: 659-665

LITERAK, I.-HEJLIČEK, K.: Incidence of Toxoplasma gondii in populations of domestic birds in the Czech Republic. Avian pathology, 22, 1993: 275-281

LUKEŠOVÁ, D.-HEJLIČEK, K.-KEJfKOVÁ, M.-KEJIK, P.-PUNČOCHÁR̆, P.: Sarkocystóza a toxoplazmóza v chovech králíkú. Veterináłství, 34, 1984, 120-122

MALUKIENE, L. I.: Eksperimentalnoje izuČenije zakonomernostej cirkuljacii toksoplazm sredi travojadnych selskochozjajastvennych životnych na modeli domašnego krolika. 1. Trava kak faktor peredači toksoplazm krolikam. Acta parasitol. lithuan, 23, 1989: 67-73 
MALUKIENE, L. I.: Eksperimantalnoje izučenije zakonomernostej cirkuljacii toksoplazm sredi travojadnych selskochozjajstvennych životnych na moděli domašnego kroloka. 2. Immunogumoralnaja reakcija organizma krolika na zaraženije oocistami toksoplazm. Acta parasitol. lithuan., 23, 1989: 74-82

MANFREDINI, L.: Histological and serological studies on five outbreaks of toxoplasmosis in the rabbit (Oryctolagus cuniculus). Clin. veter., 101, 1978: 295-314

PEETERS, J. E.-HALEN, P.: Two outbreaks of toxoplasmosis in rabbits. Vlaams diergeneesk. Tijdscgr., 47, 1978: 30-38

PEETERS, J. S.-MEULEMANS, G.-HALEN, P.: Enquete sérologique sur la toxoplasmose du lapin par le test d'immunofluorescence indirecte. Ann. Méd. véter., 123, 1979: 39-45

ROMMEL, M.-BREUNING, J.: Untersuchungen über das Vorkommen von Toxoplasma gondii in der Milch einiger Tierarten und die Möglichkeit der laktogenen Infektion. Berl. Münch. tierärztl. Wschr., 80, 1967: 365-369

SIMA, O.-RAŠ́fN, K.: Toxoplasma gondii Nicolle et Manceaux 1909 -protilátky u domácích králíkủ. Veter. Med. Praha, 18, 1973: 633-640

TERRAGNA, A.-MORANDI, N.-CANESSA, A.-PELLEGRINO, C.: The occurrence of Toxoplasma gondii in saliva. Tropenmed. Parasitol., 35, 1984: 9-10

UHLfKOVÁ, M.-HÚBNER, J.: Congenital transmission of toxoplasmosis in domestic rabbits. Folia parasitol., 20, 1973: 285-291

WERNER, H.-JANITSCHKE, K.-MASILU, M.-ADUSU, E.: Ưber die Wirkung von ToxoplasmaAntikörpern auf $T$. gondii nach Reinfektion. III. Untersuchungen über die Frage des plazentaren Übergangs der Toxoplasmen bei immunisierten trächtigen Versuchstiren. Zbl. Bakt. Hyg., I. Abt. Orig. A 238, 1977: 128-142

WICKHAM, N.-CARNE, H. R.: Toxoplasmosis in domestic animals in Australia. Aust. veter. J., 26., 1950: 1-3

ZARDI, O.-ADORISIO, E.-LILLINI, E.-PIRAGINO, S.-AMADDEO, D.-ALEANDRI, M.: Toxoplasmosis in rabbits. XXI. Vsemirnyj veter. kongr., kratkije soobšcenija, rezjume, Moskva, 21, $1979,2 / \mathrm{III}, 50$

ZÁSTÉRA, M.-HÜBNER, J.-POKORNÝ, J.-SEEMAN, J.: Králíci jako možný zdroj toxoplazmické infekce člověka. Ceskoslov. Epidem. Mikrobiol. Imunol., 15, 1966: 172-177. 